International Journal of Linguistics, Literature and Translation

ISSN: 2617-0299 (Online); ISSN: 2708-0099 (Print)

DOI: $10.32996 / \mathrm{ijllt}$

Journal Homepage: www.al-kindipublisher.com/index.php/ijllt

\title{
Metacognitive Learning Strategies: Their Effects on the Reading Comprehension Performance of Grade Five Pupils
}

\author{
Farraniva Acmed-Ismael, Ph.D. 8 (i) \\ Faculty Member, Chairperson, Coordinator and Researcher of Mindanao State University, Marawi City, Lanao del Sur, Philippines \\ $\triangle$ Corresponding Author: Farraniva Acmed-Ismael, E-mail: ismael.fa85@s.msumain.edu.ph
}

ARTICLE INFORMATION ABSTRACT

Received: April 11, 2021

Accepted: May 02, 2021

Volume: 4

Issue: 5

DOI: $10.32996 / i j l l t .2021 .4 .5 .10$

\section{KEYWORDS}

Metacognitive Strategy, Reading Comprehension, Basal Readers

Approach
This study aimed at examining the effects of metacognitive learning strategies on the reading comprehension performance of 80 Grade Five pupils in the MSU-Integrated Laboratory School for SY 2011-2012. The researcher used quasi-experimental design, which entailed using two intact, randomly selected groups: one served as the control group and the other as the experimental group. The descriptive-quantitative research was used to describe and analyse the respondents' performance in their reading comprehension test. The data were treated using Statistical Program for Social Sciences (SPSS) with a significance level set at .05. This research work involved four phases: In the first phase, a self-constructed Personal Background Questionnaire and the Strategy Inventory for Language Learning (SILL) by Oxford (1990) were administered both to the experimental and control groups before the strategy instruction. In the second phase, the experimental group received six sessions of instruction on metacognitive strategies. On the other hand, the control group received six sessions of instruction using the traditional method of teaching reading based on the Basal Readers Approach. Both experimental and control groups worked on authentic and inauthentic texts (some articles from the Newspaper and the World of Reading textbook). In the third phase, after completion of instruction, the teachermade reading comprehension test was administered to both groups to determine the reading comprehension performance of the respondents. In the fourth phase, the SILL was administered to both groups again to determine if the metacognitive strategies instruction has an effect on the reading comprehension performance of the respondents. The data analysis yielded the following findings: First, a slightly greater outcome was manifested in the reading comprehension test of the experimental group compared to the control group. Second, there was no significant difference between the mean scores of the reading comprehension test of the control and experimental groups. Both the experimental and control groups performed well in the authentic section of the reading comprehension test. Lastly, the Strategy Inventory for Language Learning (SILL) by Oxford, 1990 shows a positive effect on the reading comprehension performance of the experimental group. Therefore, the respondents performed better in the part of the reading comprehension test using authentic texts and the experimental group's metacognitive awareness increased notably after the instruction.

\section{Introduction}

The most important goal of education is to teach students how to learn on their own. According to Bruner (1996), "The child is not merely ignorant or an empty vessel, but somebody able to reason, to make sense, both on her own and through discourse with others. The child... is capable of thinking about her own thinking, and of correcting her ideas and notions through reflection-by 'going meta', as it is sometimes called." 'Meta' in the sense that Bruner (1996) uses it concerned with learners reflecting on their

\begin{tabular}{l|l|l}
$\mathbf{K}$ & $\mathbf{C}$ & AL-KINDI CENTER \\
$\mathbf{R}$ & $\mathbf{D}$ & FOR RESEARCH AND
\end{tabular} DEVELOPMENT

Your gateway to world-class research

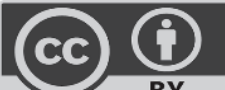

Published by Al-Kindi Center for Research and Development, London, United Kingdom. Copyright (c) the author(s). This open access article is distributed under a Creative Commons Attribution (CC-BY) 4.0 license 
own views and those of others about something, and developing a more reasoned idea through that reflective process, and it must be added, "creating bridges of their own." Enlightenment or elucidation of ideas through reflection is further supported by Dewey (1910).

It is vital that students acquire the skills to learn as these skills enable them to learn not just while they are in school but also for a lifetime. This entails a deeper awareness of how one processes information, evaluate his own thinking and think of ways to make his own learning process more effective. The goal of instruction is not to fill the mind of the learner with information or contents of various kinds but to train his mind to learn. Furthermore, one significant mission of every educator is to help instil in the learner the right attitude that learning is a lifetime task requiring a self-directed process. Thus, learners should be provided with skills that will empower them to adapt and respond to changing demands and make them continue learning independently even after they put behind them formal schooling. In language teaching, much attention should be given to raising learners' awareness that they will have to go on learning the language autonomously to independently manage and take control over the learning process (Lucas, 2007).

For many years, one of the major persisting problems encountered by the reading teacher in elementary like this researcher is the inadequate comprehension skills of the learners. This was made evident by teachers' observations of pupil's slow decoding strategies and weak comprehension skills. It was also noted that pupils did not make use of higher-order thinking skills when responding to comprehension activities. Such difficulties cause teachers and students alike no mean measure of frustration.

Students with reading problems are common in most classes and it is not at all a surprise that these are the same individuals showing minimal progress academically. A number of local and national examinations also provide proof that Filipino students' reading performance in English needs to be enhanced. Thus, there is a compelling need for research into the effective instructional approaches for teaching reading comprehension. Such research can provide guidance for teacher education, instructional materials, and curriculum development.

Reading deficiency is a common phenomenon in schools throughout the Philippines. In fact, in MSU-Integrated Laboratory School, teachers have been complaining about the poor reading comprehension of some of their students. The reading teachers have perceived that poor reading performance could be a factor behind the poor academic performance of the students. According to Palasan (1999) and Ilupa (1995), it is lamentable to note that there are even Grade Five and Six pupils classified as slow readers and some who could not decode even single words. Simple calculations would lead one to the conclusion that those pupils indeed suffer from some learning disability. If they cannot handle single words, how much larger units like phrases and clauses, or longer stretches of discourse.

There are a number of instructional approaches for reading comprehension. Reading teachers could choose from a wide variety of strategies or techniques. One of these is metacognitive instruction which is based on the concept that expert readers are metacognitive, that is, "they are aware of and in control of cognitive reasoning processes associated with constructing meaning from text" (Hermann, 1983). Being metacognitive readers, they analyze their reading tasks by "setting the purpose for reading and then selecting the right strategies for getting it done" (Paris et. al., 1983). Reading therefore, is viewed as a process in which an active reader gains meaning through interaction, for example, between his background knowledge and information in a text with the use of metacognitive strategies. Consequently, reading teachers are confronted with the challenge of teaching students' metacognitive strategies, which, according to Sanacore (1984), "has the potential for improving reading performance."

The researcher believes that pupils can achieve optimal learning given the proper conditions. They need to be properly guided by using appropriate texts and teaching strategies, making sure that the language used in the text is suitably pitched to the pupil's proficiency, providing pupils with a variety of reading materials, utilizing various reader-response activities and utilizing the levels of comprehension. These conditions should ensure that there is no reason why reading comprehension cannot be attained as well as the higher-order thinking skills.

The study was conducted in response to the need of the Grade Five pupils of the MSU-Integrated Laboratory School to improve their reading comprehension skills using metacognitive strategies which numerous researchers have found to have beneficial or salutary effects on the learning process. Thus, this study hoped to shed more light on this topic of interest in order for Reading teachers to gain more significant insights on ways to empower learners with metacognitive strategies, thereby making them more competent to cope with the demands of their academic courses and, hopefully, their future professional pursuits.

\section{Conceptual Framework}

This study was guided by the theories and principles of Metacognition, Schema Theory, Information Processing Theory, Interactive Theory, Mental Model Theory, Proposition Theory, and Learning Strategy and Cognitive Theory. 
The conceptual framework of the study shows the interplay of the independent and dependent variables, which is the focus of interest of this study. It highlights the activities that the two groups involved in the study engaged in, namely: the experimental group that was exposed to the metacognitive learning strategies and the control group that was taught, using the traditional reading techniques from the Basal reading approach.

This study was undertaken to find out the effects of metacognitive learning strategies on the reading comprehension performance of the Grade Five pupils of MSU-Integrated Laboratory School, SY 2011-2012. Thus, the choice of the effect of metacognitive strategies (Centering, Arranging and Planning, and Evaluating your Learning) instruction on the learner's reading comprehension performance as the focal interest of this inquiry. Furthermore, it was also intended to investigate the probable effect of text type (authentic and inauthentic texts) on the learners' performance in reading comprehension tests. Moreover, this research explored the effect of metacognitive strategies instruction as measured by the Strategy Inventory for Language Learning (SILL) on the learners.

Specifically, this study sought to answer the following questions:

1. What is the reading comprehension performance of the experimental group and the control group on authentic and inauthentic texts reading test?

2. Is there any significant difference between the mean scores of the reading comprehension test of the control group and the experimental group?

3. What is the effect of the metacognitive strategies, as measured by the Strategy Inventory for Language Learning (SILL), on the reading comprehension performance of the experimental group?

\section{Literature Review}

The following studies were found to have relevance for the present investigation since they deal with effective reading comprehension using metacognitive instruction:

Lojean Valles Akil (2003) presents the results of a study about the effect of metacognitive instruction on students' reading performance. The study specifically sought to find out whether instruction on metacognitive awareness would result in better reading comprehension of students. The data showed that the experimental group and control group were comparatively equivalent at the start of the experiment since there was no significant difference in the pre-test mean scores between the two groups. However, a significant difference in the post-test mean scores was found in favor of the experimental group at the end of the experiment. A significant increase in scores on the post test was determined for the experimental group that underwent metacognitive instruction.

Faith Ongpoy Miguel (1996) carried out a study entitled, "Metacognitive Learning Strategies in Reading: Their Effects on Writing Competence." The study looked into the relative effects of the metacognitive strategies (MCS) developed in reading on the writing competence of the freshmen college students. Furthermore, it tried to find out the relative contributions of readingwriting attitudes, reading interests and reading proficiency to their writing competence. Some 104 college freshmen students enrolled in the Physical Therapy program of the Iligan Medical Center were the subjects of this study. The findings of the study revealed that metacognitive learning strategies employed in reading had a positive effect on reading interest, reading comprehension, reading-writing attitude, metacognitive inventory, and the writing competence of the learners. Therefore, the study implies that integrating the teaching of Metacognitive Strategies in reading lessons will have favorable effects on the development of the learners' writing competence.

\section{Methodology}

The researcher used quasi-experimental design and descriptive-quantitative method. This quasi-experimental design employed two intact randomly selected groups; one served as the control group and the other as the experimental group. Furthermore, a descriptive method was used to analyse and describe the pupils' performance in their reading comprehension test. On the other hand, the quantitative method was employed to determine the numerical data on the reading comprehension test scores and Strategy Inventory for Language Learning (SILL). Gains scores of both experimental and control groups were compared and statistically computed.

This study involved four phases. In the first phase, a Personal Background Questionnaire (PBQ) and Strategy Inventory for Language Learning (SILL) by Oxford (1990) were administered both to the experimental and control groups before the strategy instruction. The Personal Background Questionnaire (PBQ) was used in SILL research studies to provide additional information on pupil characteristics. This information helped teachers and students to better understand the SILL results in context (Oxford, 1990). Furthermore, SILL assesses the frequency with which the subjects use a variety of techniques for foreign language 
learning. In the second phase, the experimental groups received six instruction sessions on metacognitive strategies: Centering, Arranging and Planning, and Evaluating learning based on the Cognitive Academic Learning Approach (CALLA). The control group during the same period received six sessions of instruction using the traditional methods of reading, using the techniques from the Basal Readers Approach. Both experimental and control group worked on authentic and inauthentic texts (some articles from the Newspaper and the World of Reading 5). In the third phase, after completion of instruction, a teacher-made reading comprehension test was administered to all groups to determine the reading comprehension performance of the respondents. In the fourth phase, Strategy for Inventory Language Learning was administered to all groups again to determine if the reading instruction has an effect on the reading comprehension performance of the respondents.

\section{Findings}

In this study, the data are presented, examined and analysed in detail, and interpreted with reference to the study's problems. These data are presented following the sequence of the problems stated above.

Problem 1. What is the reading comprehension performance of the experimental group and the control group on authentic and inauthentic texts on reading test?

\subsection{Experimental Group}

\section{Table 1.1: Scores of the Experimental Group on Reading Comprehension Test} Using Authentic Text

\begin{tabular}{|c|c|c|c|}
\hline Scores & Mean & $\mathbf{N}$ & Std. Deviation \\
\hline 10 (min) & 11.00 & 1 & \\
\hline 13 & 11.50 & 2 & 3.536 \\
\hline 14 & 13.25 & 4 & 2.872 \\
\hline 15 & 13.33 & 6 & 4.457 \\
\hline 16 & 16.75 & 4 & 4.856 \\
\hline 17 & 14.75 & 4 & 4.272 \\
\hline 18 & 15.50 & 4 & .577 \\
\hline 19 & 18.40 & 5 & 3.647 \\
\hline 20 & 16.50 & 4 & 4.796 \\
\hline 21 & 17.00 & 2 & 2.828 \\
\hline 22 & 17.00 & 3 & 4.583 \\
\hline 23 (max) & 21.00 & 1 & . \\
\hline Total & 17.30 & 40 & 2.972 \\
\hline
\end{tabular}

Table 1.1 above shows the total scores of the experimental group on the reading comprehension test using newspaper article as authentic text. The number of respondents is 40 . The highest score is 23 and the lowest score is 10 out of 25 items. The total mean score of the test given is 17.30 and the standard deviation is 2.972 . These show that the total mean is high with a very low standard deviation implying that almost all the respondents' answers were nearly the same. From the data above, it can be inferred that the majority of the respondents passed on this test item with a total percentage of $97.5 \%$. Their scores were close or up to the mean perhaps because most of the respondents learned and practiced the metacognitive learning strategies to easily comprehend the reading test.

Therefore, the data reveal a good overall score obtained by the respondents in the experimental group. They got a higher score of 23 points out of 25 items and 10 points as the lowest score. This means that most of the respondents performed better in the comprehension test after exposure to instruction based on metacognitive learning strategies.

Table 1.2: Scores of the Experimental Group on Reading Comprehension Test Using Inauthentic Text

\begin{tabular}{|l|c|c|c|}
\hline \multicolumn{1}{|c|}{ Scores } & Mean & N & $\begin{array}{c}\text { Std. } \\
\text { Deviation }\end{array}$ \\
\hline $\mathbf{9}$ (min) & 15.00 & 4 & 1.633 \\
\hline
\end{tabular}




\begin{tabular}{|c|c|c|c|}
\hline 10 & 17.00 & 2 & 4.243 \\
\hline 11 & 10.00 & 1 & \\
\hline 12 & 19.00 & 2 & 4.243 \\
\hline 13 & 14.50 & 4 & .577 \\
\hline 14 & 16.25 & 4 & 2.500 \\
\hline 15 & 18.00 & 4 & 2.449 \\
\hline 16 & 18.75 & 4 & .957 \\
\hline 17 & 14.00 & 1 & \\
\hline 18 & 18.20 & 5 & 2.387 \\
\hline 19 & 20.50 & 2 & .707 \\
\hline 21 & 19.80 & 5 & 3.114 \\
\hline 23 (max) & 17.50 & 2 & 2.121 \\
\hline Total: & 15.48 & 40 & 4.025 \\
\hline
\end{tabular}

On the other hand, Table 1.2 presents the scores of the experimental groups on the reading comprehension test using textbook in reading as an inauthentic text. It shows the mean scores of the experimental group on the reading comprehension test based on the book as an inauthentic text. As shown above, the highest score is 23 and the lowest score is 9 out of 25 items. The number of respondents is 40 . The total mean score of the test given is 15.48 and the standard deviation is 4.025 . These show that the mean result is high (15.48) with a very high standard deviation (4.025). It can be seen in the table that the scores of the respondents in the reading test are high and the ranges of the respondents' scores vary from one another. This could only be attributed to the constant use of metacognitive learning strategies.

To sum up, the data revealed that the experimental group also performed better in inauthentic texts after the instruction on metacognitive strategies compared to the control group. Thus, a comparison of the two-test result seems to imply that it is the use of metacognitive learning-based instruction that made the difference. Inauthentic texts could produce the same outcome as authentic texts when mediated by instruction on metacognitive learning strategies.

\subsection{Control Group}

Table 1.3: Scores of the Control Group on the Reading Comprehension Test Using Authentic Text

\begin{tabular}{|l|c|c|c|}
\hline \multicolumn{1}{|c|}{ Scores } & Mean & N & Std. Deviation \\
\hline $\mathbf{8}$ (min) & 5.00 & 1 &. \\
\hline 9 & 11.00 & 1 &. \\
\hline 10 & 8.00 & 1 &. \\
\hline 11 & 18.00 & 1 &. \\
\hline 12 & 22.00 & 1 &. \\
\hline 13 & 15.00 & 1 &. \\
\hline 14 & 13.50 & 4 & 2.082 \\
\hline 15 & 13.40 & 5 & 2.881 \\
\hline 16 & 14.75 & 8 & 2.765 \\
\hline 17 & 14.40 & 5 & 2.408 \\
\hline 18 & 19.00 & 4 & 2.944 \\
\hline 19 & 19.00 & 2 & .000 \\
\hline 20 & 18.75 & 4 & 4.992 \\
\hline $\mathbf{2 1}(\mathbf{m a x})$ & 19.00 & 2 & 2.828 \\
\hline & $\mathbf{1 5 . 9 8}$ & 40 & $\mathbf{3 . 0 9 2}$ \\
\hline
\end{tabular}

The table above shows the total scores of the control group on the reading comprehension test using newspaper article as authentic text. The number of respondents is 40 . As it turned out, the highest score is 21 and the lowest score is 8 out of 25 items. The total mean score of the test given is 15.98 and the standard deviation is 3.092 . This means that the average mean is 
high (15.98) with a low standard deviation (3.092). To sum up the result, the mean scores of the respondents in the control were also high and the standard deviation is very low, implying that almost all the respondents' answers were closely the same. This could only be attributed to the use of newspapers as inauthentic materials.

Table 1.4: Scores of the Control Group on the Reading Comprehension Test Using Inauthentic Text

\begin{tabular}{|c|c|c|c|}
\hline Scores & Mean & $\mathbf{N}$ & Std. Deviation \\
\hline 5 (min) & 8.00 & 1 & . \\
\hline 8 & 10.00 & 1 & . \\
\hline 10 & 15.00 & 1 & . \\
\hline 11 & 14.00 & 5 & 2.915 \\
\hline 12 & 17.00 & 1 & . \\
\hline 13 & 16.00 & 3 & 1.732 \\
\hline 14 & 15.00 & 3 & 1.000 \\
\hline 15 & 16.33 & 6 & 2.422 \\
\hline 16 & 17.50 & 4 & 3.000 \\
\hline 17 & 17.20 & 5 & 2.280 \\
\hline 18 & 15.50 & 2 & 6.364 \\
\hline 19 & 18.00 & 4 & 1.414 \\
\hline 20 & 18.00 & 1 & . \\
\hline 21 & 21.00 & 1 & . \\
\hline 22 (max) & 15.00 & 2 & 4.243 \\
\hline Total & 15.43 & 40 & 4.101 \\
\hline
\end{tabular}

The table above displays the mean scores of the control group with the use of the book as inauthentic text: 22 as the highest score 5 (out of 25 items) as the lowest score. The number of respondents is 40 . The total mean score of the test given is 15.43 and the standard deviation is 4.101. The result of the reading test shows the mean score is low as well as the standard deviation. This implies that most of the respondents answered closely the same. Their scores range from 13 to 19 points as seen in the table. Thus, there is reason to believe that it was the use of the traditional reading technique from the Basal Readers Approach that could be pin pointed as having caused the low scores of the respondents.

Problem 2. Is there any significant difference between the mean scores of the reading comprehension test of the control group and experimental groups?

Table 2.1: Results of the Paired-Sample T-tests for both Experimental and Control Group

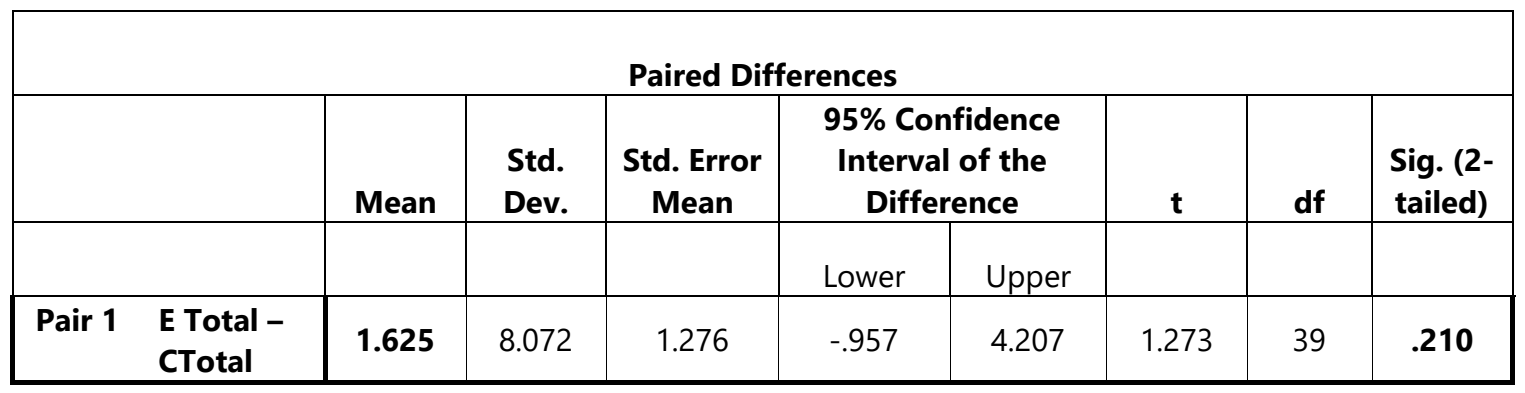

Ho1: There is no significant difference between the mean scores of the reading comprehension test of the control group and the experimental group.

Based on the test results, there was no significant difference between the mean scores of the reading comprehension test of the control and experimental groups. This warranted acceptance of the null hypothesis. This could only mean that both metacognitive strategies and traditional reading techniques are effective in teaching reading comprehension. 
Moreover, to prove that metacognitive learning strategies effectively taught reading comprehension, the paired comparison between the experimental and control groups using authentic and inauthentic texts was used. Table 2.2 presents the paired comparison in the reading comprehension test between the experimental group and control group using authentic and inauthentic texts.

Table 2.2: Paired Comparison of the Two Groups Using Authentic and Inauthentic Text

\begin{tabular}{|c|c|c|c|c|c|c|c|c|c|}
\hline \multicolumn{10}{|c|}{ Paired Differences } \\
\hline & & \multirow[t]{2}{*}{ Mean } & \multirow[t]{2}{*}{$\begin{array}{l}\text { Std. } \\
\text { Dev. }\end{array}$} & \multirow[t]{2}{*}{$\begin{array}{l}\text { Std. } \\
\text { Error } \\
\text { Mean }\end{array}$} & \multicolumn{2}{|c|}{$\begin{array}{l}\text { 95\% Confidence } \\
\text { Interval of the } \\
\text { Difference }\end{array}$} & \multirow[t]{2}{*}{$\mathbf{T}$} & \multirow[t]{2}{*}{ df } & \multirow[t]{2}{*}{$\begin{array}{l}\text { Sig. (2- } \\
\text { tailed) }\end{array}$} \\
\hline & & & & & Lower & Upper & & & \\
\hline Pair 1 & $\begin{array}{l}\text { E Authentic - } \\
\text { E Inauthentic }\end{array}$ & 1.825 & 3.706 & .586 & .640 & 3.010 & 3.114 & 39 & .003 \\
\hline Pair 2 & $\begin{array}{l}\text { EAuthentic - } \\
\text { CAuthentic }\end{array}$ & 1.325 & 3.892 & .615 & .080 & 2.570 & 2.153 & 39 & .038 \\
\hline Pair 3 & $\begin{array}{l}\text { EAuthentic - } \\
\text { C Inauthentic }\end{array}$ & 1.875 & 5.155 & .815 & .226 & 3.524 & 2.300 & 39 & .027 \\
\hline
\end{tabular}

Ho1: There is no significant difference between the mean scores of the reading comprehension test of the control group and experimental group.

Based on the finding in pair 1, the experimental group using authentic and inauthentic text has the mean score of 1.825 and a $p$ value of .003 which is lesser than the significance level set at .05. In pair 2, the experimental and control groups both using authentic texts have the mean score of 1.825 and a p-value of .038 which is lesser than the significance level set at .05. In pair 3 , the experimental group using authentic text and the control group using inauthentic texts has a mean score of 1.825 and a $p$ value of .003 which is lesser than the significance level set at .05.

A critical examination of the paired differences yields the following findings. In pair 1, it is shown that there is a significant difference between the mean scores of the reading comprehension performance of the experimental group using the authentic and inauthentic texts. In pair 2, a significant difference between the mean scores of the reading comprehension performance with the use of authentic texts for the experimental and the control groups surfaced. Pair 3 shows a significant difference between the mean scores of the reading comprehension performance using authentic text for the experimental group and inauthentic text for the control groups was found.

Based on the data shown in the table above, the null hypothesis is thus rejected. It means that the results of the three pairs are significant. Therefore, there is a significant difference between the mean scores of the reading comprehension test of the control group and the experimental groups.

Moreover, the experimental and control groups showed good reading performance in the authentic part of the reading comprehension test. The findings are in line with the positive effect of using authentic texts on the learners' reading comprehension performance and support the research findings of Takallou, 2011, Miguel, 1996,Sholichatin, 2011 and Cubukcu, 2007. So this time, it is the use of authentic texts that could be credited with the positive effect.

Problem 3. What is the effect of the metacognitive strategies, as measured by Strategy Inventory for Language Learning (SILL), on the reading comprehension performance of the experimental group?

Table 3.1: Results of the Paired Samples T-tests in the SILL Questionnaire of the Experimental Group

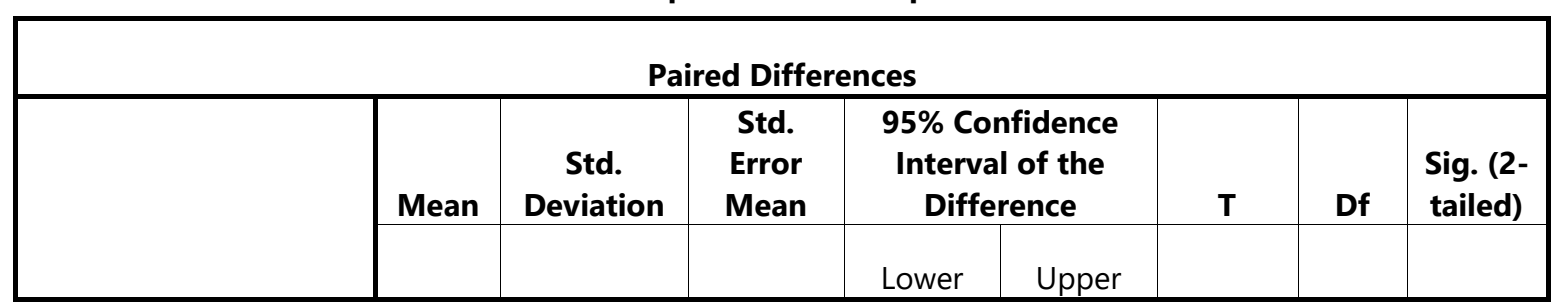




\begin{tabular}{|rl|c|c|c|c|c|c|c|c|}
\hline Pair 1 & $\begin{array}{l}\text { E Pre-SILL - E } \\
\text { Post-SILL }\end{array}$ & -.1475 & .4176 & .0660 & -.2810 & -.0140 & -2.234 & 39 & $\mathbf{. 0 3 1}$ \\
\hline
\end{tabular}

Ho2: There is no significant effect of metacognitive strategies, as measured by the Strategy Inventory for Language Learning (SILL), on the reading comprehension performance of the experimental group.

Table 3.1 presents the pre-SILL and post-SILL results of the experimental group. As shown in the table, the significance or $p$ value is 0.031 which is lesser than the 0.05 level of significance. The null hypothesis is thus rejected. It means that the result is significant therefore warranting the conclusion that there is a significant difference between the pre-SILL and the post-SILL mean scores of the experimental group in the reading comprehension performance.

The experimental group has shown significantly higher metacognitive Strategy Inventory Language Learning (SILL) (Oxford, 1990) at the beginning and at the end of the observation period compared to the control group. This could only mean that the group given metacognitive strategies instruction benefitted more by learning faster and becoming more aware of the application of metacognitive strategies than those not given metacognitive instruction.

\section{The summary of the findings is the following:}

1. The findings show a slightly greater outcome or performance was manifested in the reading comprehension test by those in the experimental group as indicated by the mean scores, compared with those of the control group.

2. There was no significant difference between the mean scores of the reading comprehension test of the control and experimental groups. This warranted acceptance of the null hypothesis. This could only mean that both metacognitive strategies and traditional reading techniques are effective in teaching reading comprehension.

3. Both the experimental and control groups performed well in authentic and inauthentic sections of the reading comprehension test.

4. Metacognitive Strategy Inventory for Language Learning (SILL) by Oxford (1990) has a positive effect on the reading comprehension performance of the experimental group.

5. The paired differences show that three pairs, namely the experimental group using authentic and inauthentic text; the experimental and the control groups both using authentic texts; and the experimental group using authentic text and the control group using inauthentic texts, have a significant difference between the mean scores of the reading comprehension test. While the other three pairs: the experimental group using inauthentic text and the control group using authentic text; the experimental and control groups using inauthentic text; and the control group using authentic and inauthentic texts, showed no significant difference.

\section{Conclusions}

On the basis of the foregoing findings of the inquiry, the following conclusions were drawn:

1. The metacognitive strategies instruction contributes to improving pupils' reading comprehension performance, thus, bearing out or validating the claims made for such approach by exponents and advocates headed by O'Malley and Chamot, David Nunan and Rebecca Oxford. More recently, the positive findings of studies conducted by Pintrich (2000) and Kivinen (2003) provide additional empirical evidence. At the same time, this finding derives support from those formulations and studies.

2. Both the metacognitive strategies and the traditional strategies in the Basal Readers Approach enhance reading comprehension. This means that the traditional method does not have to be discarded or thrown overboard with alacrity. It still has utility as shown by the only slight difference in the reading comprehension test of the experimental and control groups. Teachers can, perhaps, learn from Stevick (1996) who says that one may adopt some, rather than in toto, techniques or strategies associated with a particular method, and integrate these with a preferred method.

3. Using authentic texts in teaching reading comprehension effectively increases the students' reading comprehension performance than using inauthentic texts; the former kind abounds out there in the real world, from advertisements and songs to news reports and published letters. The contents of authentic texts draw more traction or have greater resonance for learners as they represent slices of real-life situations which connect with learners' schema (prior experience and knowledge).

4. Metacognitive strategies increase the experimental group's metacognitive awareness as measured by the Strategy Inventory for Language Learning (SILL) by Oxford (1990) after instruction. Such heightened or enhanced awareness, in turn, develops in the learners' metacognitive practices, such as elaboration, organization, reflection and critical thinking or evaluation.

5. The study was limited to the use of a teacher-made reading comprehension test. Another limitation of this study was the pupil's awareness of their participation in this experimental study, which suggests the possibility that the 
investigation conducted was not completely insulated from the so-called "observer's paradox". Such awareness could have wielded some influence on the participation and performance of the experimental group. Those who were chosen to be exposed to the treatment under study were motivated to perform well during the treatment sessions, but those who were exposed to the traditional method tended to relax. Moreover, there was another omission - i.e. lack of observers to judge the conduct of classes attended by both experimental and control groups. Finally, this study was designed as a short-term investigation due to time constraints. The experimental timetable allowed only six (6) sessions, with a time allotment of one hour per day during reading class, from Monday to Friday. Learning or mastery of metacognitive strategies takes time.

The following recommendations are hereby advanced: Reading teachers should make use of metacognitive strategies instruction in reading classes to help learners recognize the importance of awareness of the learning process: consciously centering, arranging and planning, and evaluating their own learning. Moreover, teachers/instructors should utilize authentic texts in teaching reading comprehension, such as articles from newspapers, magazines, etc. in developing lesson plans for reading classes. They should not limit themselves to, or be content and complacent with ready-made materials (for example, standard textbooks) which are too generic for comfort. More attention should be given to learners' needs, interests and learning styles. Furthermore, reading teachers must feel free to use a variety of strategies to make teaching and learning more effective. They must not adhere to only one method or strategy. The more various teaching strategies and materials employed the greater success the teacher attains in his/her effort to reach out to as many students as possible. Learner variables should always inform classroom decisions and practices. Lastly, future investigations related to metacognitive strategies should be conducted. These will look into other variables not considered in the present study, such as the following: 1. Metacognitive Learning Strategies: Their Effects on the Writing and Speaking Competencies of the Learners; and 2. the Correlation of Metacognitive Strategies with Selected Variables.

\section{References}

[1] Alawi, R. (2008). Module in ELT 200 (The Development of Language: Acquisition and Learning). Marawi City: Shakba Printing Press.

[2] Alcantara, R. et al. (1996). Teaching Strategies. Manila: Katha Publishing Co. Inc.

[3] Anderson, J. R. (1985). Cognitive Psychology and Its Implications. $2^{\text {nd }}$ ed. New York: Freeman Press.

[4] Baker, L. and.Brown, A. (1984). Metacognitive Skills and Reading. In D. Pearson (Ed.), Handbook of Reading Research. New York.

[5] Borjal, W. G. (2004). Skill Builders for Efficient Reading 5. Quezon City: Phoenix Publishing House, Inc.

[6] Brennecke, L. (2006). A Comparison of Guided Reading to Traditional Reading Instruction in Regards to Achievement. http:// lionsden.tec.selu.edu.

[7] Brown, A. (1980). Metacognitive Development and Reading. In R. Spiro, B. Bruce, and W. Brewer (eds.), Theoretical Issues in Reading Comprehension. Hillsdale, New Jersey: Erlbaum.

[8] Brown, H. D. (1987). Principles of Language Teaching. USA: Prentice Hall, Inc.

[9] Brown, H. D. (2000). Principles of Language Learning and Teaching. $4^{\text {th }}$ ed. White Plains, New York: Addison Wesley Longman, Inc.

[10] Brown, A., Armbuster B., and Baker. L. (1884). The Role of Metacognition in Reading and Studying. In J. Orasanu, Ed. A Decade of Reading Research: Implication for Practice. Hillsdale, New Jersey: Lawrence Erlbaum Associates, Inc.

[11] Bruner (1996). The Culture of Education.

[12] Caireker, S. ( 2009). Developing Metacognitive Skills: Vocabulary and Comprehension. http://www.scaneke\&neuhaus.org.

[13] Carrell, P. L. (1988). Some Causes of Text-Boundedness and Schema-Inference in ESL Reading. In P. L. Carrell, J. Devine and D. E. Eskey (eds.). 1988. Interactive Approaches to Second Language Learning. Cambridge University Press.

[14] Carrell, P. L. (1989). Metacognitive awareness and second language reading. Modern Language journal, Vol.73

[15] Chamot, A. and O'Malley, J. (1994). The CALLA Handbook: Implementing the Cognitive Academic Language Learning Approach. Reading, MA: Addison- Wesley.

[16] Chomsky, N. (1965). Aspects of the Theory of Syntax. Boston: MIT Press.

[17] Chye ,S., Walker, R. and Smith, I. (2010). Self-Regulated Learning in Tertiary Students: The Role of Culture and Self-Efficacy on Strategy Use and Academic Achievement. http://www.aare.edu.au/97pap/chyes350.htm.

[18] Cross, D. and Paris, S. (1988). Developmental and instructional analyses of children's metacognition and reading comprehension. Journal of Educational Psychology, Vol. 80 No.2.

[19] Crystal, D. and Davy, D. (1975). Advanced Conversational English. Harlow:Longman.

[20] Cubukcu, F. (2007). Enhancing vocabulary development and reading comprehension through metacognitive strategies. Educational Research,Vol. 18 No.1

[21] Eilers, L. and Pinkley, C. (2006). Metacognitive help student to comprehend all text. Reading Improvement. Spring Vol.1

[22] Ellis, R. (1994). The Study of Second Language Acquisition. Oxford: Oxford University Press.

[23] Fisher, R. (1998). Thinking about Thinking: Developing Metacognition in Children. http://www.teachingthinking.net/thinking/web\%20resources/robert.

[24] Flavell, J. H. (1976). Metacognitive Aspects of Problem Solving. The Nature of Intelligence. Ed. L.B. Hillsdale, NJ: Erlbaum.

[25] Forrest-Pressley, D. and Waller, T.(1984). Cognition, Metacognition, and Reading. New York: Springer-Verlag.

[26] Geddes and Grosset (2004). Webster's Universal English Dictionary. Manila, Philippine:WS Pacific Publication Inc. 
[27] Ghavam, Rastegar, \& Razmi (2011). Iranian EFL learners' achievement goals in relation with their metacognitive reading. English Teaching Forum: No. 2

[28] Grabe, W. (2002). Reading in a Second Language. Oxford: Oxford University Press.

[29] Guariento, W. \& Morely, J. (2001). Text and task authenticity in the EFL classroom. ELT journal, 55(4). $347-353$.

[30] Guilford, J. P. and Fruchter, B. (1978). Fundamental Statistics in Psychology: An Education. New York: McGraw-Hill Book Com.

[31] Gunning, T. G. (1996). Creating Reading Instruction for All Children. Cambridge: University Press Chapter.

[32] Harmer, J. (1991). The Practice of English Language Teaching (2nd ed.) London: Longman.

[33] Heitler, D. (2005). Newspaper Authenticity. http://www.google.com.ph/search?q=studies\%20using\%20authent.

[34] Henia, N. (2006). Applying metacognitive strategies to skimming research articles in an ESP context. English Teaching Forum. No.1

[35] Henia, N. D. (2003). Evaluating the effectiveness of metacognitive strategy training for reading research articles in an ESP context. English for Specific Purposes, Volume 22, Issue 4.

[36] Higgins, M. W. (1986). Literacy through Literature. In Literature and Reading. M.P. French and S.J. Elford, Eds. West Allis, WI: State Reading Association.

[37] Hwang, C. (2005). Effective EFL education through popular authentic materials. Asian EFL journal. Volume 7.

[38] Ilupa, (1995) The Reading Proficiency of Grade Six Pupils at MSU-Integrated Laboratory School. Master's Thesis. MSU, Marawi City.

[39] Hymes, D. (1972). On Communicative Competence. In J. B. Pride \& J.Holmes (Eds.).

[40] Javier, J. E. (2010). The Phoenix World of Reading 5. Quezon City: Phoenix Publishing House, Inc.

[41] King, A. (1991). Improving lecture comprehension: effects of a metacognitive strategy. Applied Cognitive Psychology, Vol. 5. John Wiley and Son Publisher.

[42] Laban and Sabacajan (2002). The Reading Comprehension Skills among First Year High School Students from MSU-Integrated Laboratory School, Students. Undergraduate Thesis, MSU, Marawi City.

[43] Laird, P. and Byrne (2000). The Mental Model Theory of Thinking and Reasoning. http://www.tcd.ie/Psychology/other/Ruth Byrne/mental models.

[44] Lazaraton, A. and Skuder, P. F. (1997). Evaluating Dialogue Authenticity in ESL Speaking Texts. Florida. University Press.

[45] Lee, L. V. S. (1990). Teaching Metacognitive Strategies to First Graders. Wyoming: University of Wyowing.

[46] Little, D., Devitt, S. and Singleton, D. (1989). Learning Foreign Languages from Authentic Texts: Theory and Practice. London: Modern language Publications.

[47] Lucas, M. and Corpus, B. (2007). Facilitating Learning: A Metacognitive Process. Manila: Lorimar Publishing Inc.

[48] Manda, G. (2011). The Definition of Metacognitive Skills in Education http.//www.eHow.com/how4493616.usemetacognitivestrategies.html\#1x22/QpztDuWj

[49] Mantos, L. (1992). The Effectiveness of an Eclectic Method as a Reading Instruction for Grade 6 Pupils at Mindanao State University-Integrated Laboratory School. Master's Thesis. MSU, Marawi City.

[50] Manubag, A. (2005). The Correlates of English Language Performance among High School Students of Mindanao State University- Integrated Laboratory School S. Y. 2004-2005. Unpublished Master's Thesis. MSU-Marawi City.

[51] Martinez, A. G. (2002). Authentic Materials: An Overview on Karen's Linguistic Issues. http://www3.telus.net/linguisticsissues/authenticmaterials.html

[52] Microsoft Encarta (2009). Microsoft Corporation. All rights reserved.

[53] Miguel, F. O. (1996). Metacognitive Learning Strategies in Reading: Their Effects on Writing Competence. Dissertation. MSU- IIT, Iligan City.

[54] McGregor, D. (2007). Developing Thinking, Developing Learning: A Guide to Thinking Skills in Education. The McGraw, Hill Companies.

[55] Morrow, K. (1977). Authentic Texts in ESP. In Holden, S.(Ed). English for Specific Purposes. London: Modern language Publications.

[56] Muñiz-Swicegood, M. (1994). The effects of metacognitive reading strategy training on the reading performance and student reading analysis strategies of third grade bilingual students. Bilingual Research journal.

[57] Nilsson, K. (2003). A Meta-Search Approach to Locating and Classifying Reading Material for Learners of Nordic Languages. Published Thesis, Uppsala University.

[58] Nunan, D. (1992). Research Methods in Language Learning. Cambridge:University Press.

[59] Nunan, D. and Bailey, C. (2009). Exploring Second Language Classroom Research. Philippines: ESP Printers Inc.

[60] Nuttall, C. (2000). Teaching Reading Skills in a Foreign Language. UK:Macmillan Heinemann.

[61] Nyikos, M. (1996). The Conceptual Shift to Learner-Centered Classrooms:Increasing Teacher and Student Strategic Awareness. In R. L.Oxford: University Press.

[62] O'Malley, M. J. \& Chamot, A. (1990). The CALLA Handbook. USA: Addison Wesley Publishing Company.

[63] O'Malley, Michael, J. and Chamot, A. (1990). Learning Strategies in Second Language Acquisition. USA: Cambridge University Press.

[64] O'Neill, R. \& Scott, R. (1974). Viewpoints. London: Longman Press.

[65] Oxford, R. L. (1990). Language Learning Strategies: What every teacher should know. Boston: Heinle and Heinle.

[66] Palasan, A. (1999). The Reading Proficiency, Study Habits and Attitudes of Grade 5 Pupils at MSU-Integrated Laboratory: School Basis for a Reading Instructional Design. Master's Thesis. MSU, Marawi City.

[67] Pangcatan, J. M. (2006). The Effectiveness of Dimensional Approach in Teaching Reading Comprehension among Grade 6 Pupils. MSU, Marawi City.

[68] Papango, M. (2008). On Becoming a Metacognitive and Strategic Reader. Whole School Approach to Master Reading and Writing for Successful Learning. Philippines:ESP Printers Inc.

[69] Paris, L. and Wixson A. (1983). Classroom Lessons: Integrating Cognitive Theory and Classroom Practice. Cambridge, Mass: MIT Press.

[70] Pintrich, P.R. (2000). The Role of Goal Orientation in Self-Regulated Learning. In Handbook of Self-Regulation. Ed. M. Boekaerts, P.N. Pintrich and M, Zeidner. San Diego, CA: Academic Press.

[71] Porter, G. (1999). Review of exploring spoken English. English for Language Teaching journal. Vol. 53, No.2. 
[72] Reutzel, R. and Cooter, R. (2004). Teaching Children to Read:Putting the Pieces Together. Cambridge, USA: University Press.

[73] Simpson, L. and Nist, L. (2000). An update on strategic learning: It's more than textbook reading strategies. Journal of Adolescent and Adult Literacy. Vol.43 No.6. Retrieved, November 8, 2002, from Academic Search Premier.

[74] Sholichatin, J.(2011). The effectiveness of using authentic texts in the teaching of reading comprehension. English Winter, Special Issue. No.49.

[75] Shih, S. (2005). Taiwanese sixth graders' achievement goals and their motivation, strategy use, and grades: An examination of the multiple goal perspective. The Elementary School journal. Vol. 106, No. 1

[76] Smith, B. L. (2003). The Use of Why-Questions to Enhance College Science Students' Comprehension of their Textbooks. Dissertation Abstracts International.

[77] Smith, M. (1990). A Study Skills Handbook. Australia: Oxford University Press.

[78] Sousa, D. A. (2005). How the Brain Learns to Read. Manila:Corwin Press. A Sage Publications Companies.

[79] Takallou, F. (2011). The effect of metacognitive strategy instruction on EFL: Learners' reading comprehension performance and metacognitive awareness. Asian EFL Journal Strategy Use: Open Journal of Modern Linguistics. Vol.1 No.2

[80] Tamo, D. (2009). The Use of Authentic Materials in Classrooms http:///www.authenticmaterials.com.1277547685-74 pdfsam.pdf.

[81] Tandoc, V. P. (2008). Reading Network 5. Quezon City: SIBS Publishing House, Inc.

[82] Tejero, E. G. (2002). Teaching Reading in the Elementary Grades. Mandaluyong City: National Bookstore Inc.

[83] Tonjes, M. J. (1991). Secondary Reading, Writing, and Learning. USA: Simon \& Schuster, Inc.

[84] Vahid Baghban, Z. (2011). A review on the effectiveness of using authentic materials in ESP courses. English for Specific Purposes World. Issue 31, volume 10

[85] Valles-Akil, L. (2003). Metacognitive Instruction vis-a-vis Learners' Reading Comprehension. Master's Thesis. Ateneo de Zamboanga.

[86] Villamin, A. M. et al. (1994). Innovative Strategies in Communication Arts. Quezon City: Phoenix Publishing House, Inc.

[87] Villaruel, R. P. (2007). Factors Affecting Reading Comprehension of MSU-ILS Fourth Year Students, S.Y. 2007-2008. Undergraduate Thesis. MSU, Marawi City.

[88] Vivian. (1991). Second Language Learning and Language Teaching. USA: Routledge, Chapman and Hall, Inc.

[89] Wallace, C. (1992). Reading. Oxford: Oxford University Press.

[90] Wenden, A. and Rubin, J. (1987). Learner Strategies in Language Learning. New Jersey: Prentice Hall.

[91] Whitmore, K. F. and Goodman, Y. M. (1996). Whole Language Voices in Teacher Education. York, Maine: Stenhouse Publishers.

[92] Widdowson, H. G. (1990). Aspects of Language Teaching. Oxford: Oxford University Press.

[93] Wilkins, D. A. (1976). Notional Syllabus. Oxford: Oxford University Press.

[94] Zints, M. V. (1980). The Reading Process: The Teacher and the Learner. lowa: V. M. C. Brown Company Publishers. 